\title{
The Apology of Justin Martyr and the Legatio of Athenagoras: Two Responses to the Challenge of Being a Christian in the Second Century
}

\author{
Mary Sheather \\ Australian Catholic University \\ mary.sheather@acu.edu.au; sheather.mary@yahoo.co.uk
}

\begin{abstract}
Most second-century Christians were likely to experience challenges, both internal and external, to the new way of life, belief and worship that they had adopted. With the Apology of Justin Martyr and the Legatio of Athenagoras we encounter responses to the common accusations and an exposition of those aspects of life and belief which the writers considered it important to present to ally and opponent alike. These works deal with similar issues, but from rather different perspectives, and here we attempt to draw out some of the ways in which each writer presented his case, and assess their significance and effectiveness.
\end{abstract}

\section{Keywords}

kingship - philosophy - conflict - demonic forces - logos - truth - custom - rumour

The persecution of the early Christians by the imperial government in Rome and the provinces may not have been as extensive or as persistent as it has sometimes been painted. There is, however, no doubt that most Christians were likely to experience challenges, both internal and external, to the new way of life, belief and worship that they had adopted. The need to justify belonging to this new 'ethnos' spurred a number of educated Christians to respond to the cultural and social conflict they experienced by composing works variously described as 'apologies', 'embassies' or the like, to rebut the charges alleged against them and expound the basis for their faith. The identity of their 
actual or presumed audience, whether unsympathetic emperors, suspicious officials, wary pagan neighbours or fellow-Christians - possibly harbouring a sense of inferiority over their new faith - may have varied, and may at times be hard to determine. Such groups, too, may have been more or less susceptible to the arguments brought forward. Nevertheless, the overall purpose of these works, to present membership of the Christian community as a reasonable option posing no threat to society at large, and to counteract a contrary view, is less a matter for debate, and the resulting discourses are susceptible to comparative analysis. With the Apology of Justin Martyr and the Legatio of Athenagoras we encounter responses which deal with similar issues, but from rather different perspectives. Here we will attempt to draw out some of the ways in which each writer presented his case, and assess their significance and effectiveness.

In addressing his assumed imperial auditors (2 Ap. 15.5), Justin Martyr concludes his Second Apology with the following exhortation: "May you too make a just decision that accords with your piety and your philosophy and that is in your own interest."1 Yet this mild tone is somewhat belied by what has preceded this conclusion: the direness of the situation of Christians is indicated by his tale of persecution and suspicion, his warning that "if when you have learned the true state of affairs, you do not observe justice, you will have no defence to make to God" (1Ap.3.5), while at the very beginning of the First Apology after the polite greetings, he notes that he is one of those being "unjustly hated and persecuted" (1 Ap.1.1). Athenagoras, for his part, greets his addressees as "above all, philosophers" and "greatest of kings" (Leg.1.1), yet also laments that "you allow us to be driven hither and thither and persecuted" (Leg. 1.3). ${ }^{2}$

To establish the way in which the theme of conflict to be treated here, we may note that 'conflict' is generally taken to imply a prolonged struggle of some kind, often with accompanying violence. When used rhetorically, it may also refer to a profound and ongoing difference in the way of life, view of the world, religious, cultural or political belief between two groups, or sometimes individuals, which may result in or be accompanied by organized or individual acts

1 The reference to the work being in the interest of the emperors, is, as Munier notes, a motif frequently repeated. See Justin: Apologie pour les Chrétiens, ed. Charles Munier, Paris, 2006, p. 319 , n. 4. This edition is used throughout this paper, and the numbering of the chapters in the Second Apology follows his arrangement.

2 See William R. Schoedel (Ed. and Trans.) Athenagoras: Legatio and De Resurrectione, Oxford, 1972, the edition used for references to Athenagoras' Legatio. 
of violence. ${ }^{3}$ It needs to be noted that the passages providing evidence of a situation of conflict do not negate the generally agreed current understanding which sees the early Christian community as unselfconsciously sharing many of the Greco-Roman cultural assumptions of their day. Persecution and misunderstanding by the authorities might suggest mutual hostility, but the former was not constant and the latter was not total. ${ }^{4}$ Christian attempts to placate a ruler not surprisingly are likely to adopt the kind of rhetorical devices set forth by Menander 5 and do not have the flavour of a declaration of hostilities or open confrontation. Evidence of conflict is therefore likely to be more subtle. The compatibility of the world views being presented is what is at stake. How much could a conscientious Christian like Justin or Athenagoras concede? How far did the authors go down the track of conciliation or the seeking of common ground, starting from a shared central understanding, and how far did they challenge or confront the pax Romana and all that it stood for?

To investigate this we will look for terms and expressions which may be described as conciliatory in tone and also see how far the language used may break with the generally irenic approach to suggest fundamental differences which would, in the case of Justin's work, make his acquisition of the title of martyr entirely comprehensible. We will also examine the foundational assumptions evident in the works for hints of a radical incompatibility.

One point at issue is whether the works to be examined here were actually intended to come to the attention of the emperors to whom they were addressed, or whether this was a pleasing fiction designed to impress on potential readers, pagan or Christian, the importance of the works and the seriousness

3 Wendy Mayer, "Religious Conflict: Defintions, Problems and Theoretical Approaches, " in Religious Conflict from Early Christianity to the Rise of Islam, edited by Wendy Mayer, Bronwen Neil and Christian Albrecht, 2013 online, provides a helpful framework for exploring the concept of religious conflict in a chapter which outlines the theoretical perspectives which have emerged in recent scholarship within the area.

4 Helpful insights into the context in which these works were produced are provided by the relevant chapters within The Early Christian World, first edition, 2 vols, edited by Philip F. Esler, London and New York, 200o. Robin Lane Fox, Pagans and Christians, London, 1986 provides a different perspective, while Wayne A. Meeks in The Moral World of the First Christians, Westminster, 1986 and The Origins of Christian Morality: The First Two Centuries, New York and London, 1993 delves further into social and cultural perspectives than the titles might suggest. Judith M. Lieu, Christian Identity in the Jewish and Graeco-Roman World, Oxford, 2004 and Robert L. Wilken,The Christians as the Romans Saw Them, second edition, New Haven, 2003 explore in depth, although from different angles, the contentious issue of early Christian identity and participation in relation to society and the empire.

5 As noted by Schoedel, Athenagoras, p. xvi, n. 24. 
of the claims being made. ${ }^{6}$ Clearly, whatever the avowed or actual intention, the tone throughout suggests an appeal to an authority which, being benevolent and intelligent, was likely to give a favourable hearing. Just as clearly this outcome was very remote. If the writers' real aim was to be seen as encouraging their fellow-Christians and not in fact genuinely engaging with the powersthat-be, their implicit criticism of the status quo clearly will have a rather different compositional purpose.

Nevertheless, that the apparent addressees were emperors or their imperial colleagues indicates that this approach must have been assumed to be effective in catching the attention and approval of the Christians or potential converts who were the actual audience. Verisimilitude would have to be maintained for this to be an effective ploy. Yet this apparently calm and rational approach is clearly not the whole story. The 'enemy' may be hard to pin down, and changeable, and the literary encounters civil, but this is no academic production. It is also important to note that there are hints that the co-existence - indeed conversion - being advocated by our writers was proclaimed simply as a self-evident good for a political order that could remain essentially unchanged in its political functioning if, by a miracle of rhetorical persuasiveness, a change

6 Views on this vary widely. Thus Leslie Barnard maintains that one should not be too sceptical about the historical basis of the Legatio that is suggested in Leg. 11 ( in L. Barnard, "The Embassy of Athenagoras," vc, 21 (1967), p. 92), and R. Grant "Five Apologists and Marcus Aurelius," Vc, 42 (1988), pp. 8-9 is similarly prepared to accept its avowed setting. On the whole more recent commentary is less confident that the scenario suggested is credible, although William R. Schoedel, "Apologetic Literature and Ambassadorial Activities," HTR., 82(1989), 55-78, concludes that Athenagoras wrote the Legatio with the intention of having it presented, even if this was in fact highly unlikely (pp. 74-75). He concedes that it is even less likely that Justin ever had the opportunity to present or deliver his work (p. 77). Barnard, in Justin Martyr: His Life and Thought, Cambridge, 1966, is also ready to consider the possibility that Justin's apologies may have reached the emperors (p. 15). Laura Nasrallah, Christian Responses to Roman Art and Architecture: The Second-Century Church amid the Spaces of Empire, Cambridge and New York, 2010, reflects on the likelihood or not of actual contacts (pp. 27, 133.) On the side of scepticism, P. Lorraine Buck,"Justin Martyr's Apologies: Their Number, Destination and Form," JThS, 54 (2003), pp. 45-59, finds the 'contumely' displayed by Justin one argument among several against accepting the works as intended for an imperial hearing (p. 56), despite the dedication. Silke-Petra Bergian, "How to Speak about Early Christian Apologetic Literature? Comments on the Recent Debate," Studia Patristica, 36, Leuven, 2001, edited by M.F. Wiles, E.J. Yarnold and P.M. Parvis, pp. 177-183, while assessing the arguments for an intended 'insider' reader or an imperial readership, examines existing models for such addresses, and prefers to focus on the range of prototypes available, none of which, she finds, presents an exact model. 


\section{of heart were to be effected. No radical alteration of the status quo is seriously envisaged or proposed. ${ }^{7}$}

There is still considerable debate also about the correct description for the works to be considered here, whatever their declared or actual audience. The blanket term apology is often used for any writings from this period written by Christians with the avowed or implicit goal of rendering Christian belief and practice more intelligible - and less threatening - to bemused pagans or even the newly converted. ${ }^{8}$ Many scholars have reservations about the use of the term 'apology' employed for such a range of writings, ${ }^{9}$ and we may note that in

7 Such endorsement of the established order is not at one level surprising. It reflects the ambiguous nature of the Christian critique of societal norms. J. Albert Harrill, Slaves in the New Testament: Literary, Social, and Moral Dimensions, Minneapolis, 2006, discussing the references to slaves and slavery to be found in early Christian writers, including the New Testament texts, concludes that no challenge was ever issued to the status quo, but rather that there was a reapplication of the usual terminology. Such works, while counselling householders to display moderation and fairness to inferiors, including slaves, did not question or in any way challenge the existence of the hierarchy. In regard to drawing conclusions on relations between Christian masters and slaves from such sources, Harrill sees the different accounts of slave behaviour - Athenagoras asserting ( Leg. 35.3) that no slave has ever accused a Christian master of the slanderous behavior alleged of the sect, Justin (2Ap.12.4) blaming accusations by disgruntled slaves for the unfounded rumours circulating - as arising from the stereotypes of the faithful and rebellious slave, rather than from any foundation in actual situations (p. 153). His approach is a useful corrective to the tendency to find more evidence for the revolutionary nature of early Christianity than is warranted by the evidence, but itself begs the question of why the different stereotypes might have been found applicable or useful in the two works.

8 "Defence in the sense of justification has much in common with attack," notes Simon Swain in "Defending Hellenism," Apologetics in the Roman Empire, edited by M. Edwards, M. Goodman and S. Price in association with C. Rowland, Oxford, 1999, p. 190, and it is this that gives a work which may appear as a simple explanation of a way of life its cutting edge.

9 See, for example, on the term 'apologia' the article of Kerestzes, who concludes that Justin's apologia is more properly to be seen as a letter of advice to the emperor and discounts its in-house audience (Paul Keresztes, "The Literary Genre of Justin's First Apology”, vc, 19 (1965),pp. 99-110). See also Jean-Claude Fredouille, "L'apologétique chrétienne antique; naissance d'un genre littéraire," RÉA, 38 (1992), pp. 219-234 for a thorough discussion of the nature of this somewhat amorphous genre. Anthony J. Guerra, "The Conversion of Marcus Aurelius and Justin Martyr: The Purpose, Genre and Context of the First Apology," The Second Century: a Journal of Early Christian Studies, 19 (1992), pp. 171-196, suggests that Justin's apology follows the traditional protreptic pattern and had the conversion of the emperors, as well as the end of persecution, as its ultimate goal, which would suggest a high degree of optimism on Justin's part! 
their response to the accusations made against their fellow-Christians, Justin and Athenagoras used a number of terms to describe what they were about, although such usage still leaves the actual context of the works open to conjecture. Justin refers to the appeal-biblidion - of the wife who was pursued by her husband for converting to Christianity and seeking time to arrange her affairs before being prosecuted, and is thus wishing to "defend herself against the charges" (2Ap. 2.8), and he also describes his own composition in this way (2Ap.14.1), although he also uses the word suntaxis (2 Ap.1.1).There is thus no clear and distinct term which covers exactly, and only, what we find here. What we have to consider, however, is whether the works produced under these circumstances emerge as polemical diatribes fighting a battle on behalf of the faith, and if not how does the tone of each work acknowledge the situation that produced it? ${ }^{10}$

\section{How are the Rulers Addressed?}

\section{Justin}

If we turn to Justin's vision, set forth to assuage the rulers' alarms and provide enlightenment before doom overtook them, what do we find? Does he in fact assume a situation of conflict or attempt to play down or ignore it? We may note, in this connection, Rajak's observations in relation to Justin's other key writing, allegedly directed at the Jews: "establishing a polarity, drawing attention to an enemy and making the most of a conflict are reliable techniques of advocacy. The effect is more memorable, and therefore more persuasive, than merely stating a case."11 In the Apologies, however, Justin is more circumspect. His 'enemy', and the aggressor as far as Christians were concerned, was a pagan ethos linked to a dominant political force, and the response here was of necessity more amorphous and less personal.

The assumed addressees of Justin's apologies are the imperial authorities Emperor Antoninus Pius and Caesars Lucius Verus and Marcus Aurelius (both the latter titled philosophers) and for form's sake, the senate and people of Rome (1Ap. 1.1) with a presumed date of composition of $153-154 \cdot{ }^{12}$ In chapter

10 Note also the comments of Helen Rhee, Early Christian Literature: Christ and Culture in the Second and Third Centuries, London and New York, 2005, pp. $22 \mathrm{ff}$. and $164 \mathrm{ff}$., in relation to the rhetorical form and intent of the Christian apologetic writings. 
two of the so-called Second Apology the emperor is specifically addressed (2Ap. 2.8) while at $2 A p .14 .1$ and 15.4 in the summing up, the appeal for a fair hearing is directed at the royal recipients (in the plural).

The rulers are appealed to as susceptible to the voice of reason. Justin suggests that certain points need to be made to clarify misunderstandings, and he suggests that it is in the rulers' interests to listen ( $1 A$ p. 8.1; cf. 16 and 18 , and note the emphasis on 'right reason' in $1 A p .17$ ), with Justin implying (1Ap.20.3) that an appeal to the rulers with their attachment to philosophy, if not access as yet to the whole truth, will rely on their good judgement for success (cf. $1 \mathrm{Ap} .12$ and 14). What is needed is an investigation of where truth lies (1Ap. 14.4-5 and 16.4), and, so Justin asserts, he will not be trying to succeed by flattery (2.Ap 2-3).

In the First Apology, as it has come to be referred to, the reference to persecution is muted, but certainly in the Second Apology we find an account of the wife who converted and who, along with her spiritual supporter, was threatened with execution. The Cynic philosopher Crescens is introduced here as someone liable to accuse a Christian rival such as Justin, and the reality of execution is vividly presented when Justin records the castigation of the prefect by the soon to be martyred Lucius in terms suggesting that the condemnation of Christians would not do honour to the reputation of the emperor, the Caesars or the senate. ${ }^{13}$

The way in which the name 'Christian' was regarded was of great significance to adherents, since the mere acknowledegement of membership of the Christian sect would have them categorized as criminals, regardless of behaviour. It is therefore not surprising that Justin responded to the negative connotations attached to the word by defending the name from the outset as indicative of a higher ethical standard to be found in those who embraced the title of Christian. Thus reference to the name features often in these works as Justin makes his defence, in literary setting at least, before the rulers. He describes the name as unremarkable in the sense of not automatically tainted: if anything the word suggests, as pronounced, one who is virtuous and certainly no fit object of suspicion ( $1 A$ p. 4.3), and thus the name alone should not merit condemnation. Developing this theme further he points out that philosophers in general consider deeds and not mere appellations an indicator of blame- 
worthiness (1Ap.4-5), yet, as he observes, the punishment of death is decreed for mere adherence to the name of Christ (1 Ap.45.5; cf. 1 Ap.24.1). ${ }^{14}$

\section{Athenagoras}

The assumed auditors of Athenagoras' Legatio are Marcus Aurelius and his son Commodus, and the work is generally thought to have been composed in about $176 \mathrm{CE},{ }^{15}$ with suggestions of indebtedness to Justin's Apologies. He provides the background for his exposition by referring to the persecution experienced by his co-religionists (Leg. 1.3), and like Justin refers in the opening of his address to the rulers as "above all philosophers" (Intro.), presumably responsive to reasonable arguments. ${ }^{16}$

He explains that he has dared to set forth an account to vindicate the position of Christians. The tone is forthright, but the writer steers a careful line between accusation of unfair treatment at the hands of emperors and exoneration of them from responsibility by placing the blame on informers and the wrong-headed views of the many -oi polloi (Leg.1.3). It is suggested that the empire is able to cope with a degree of variety in customs and laws, and hence as ancestral ways do not incur legal penalty so too Christians should be tolerated (Leg.1.1).

Like Justin, Athenagoras objects to the opprobrium cast on the name itself regardless of any substantiated crimes committed by those calling themselves Christian (Leg. 2.1), and he proceeds to develop this point in several places, suggesting that names by themselves should not incur hatred, particularly this name (see Leg. 1.3; 2.4).

14 Schoedel, "Apologetic Literature" sees the aim of both Justin and Athenagoras as "eliminating prejudice by clearing the name Christian of the evil association it had" (p. 74). Clearly if the texts remained within the community, this intention could hardly be realized although the mention of such a goal might assist the morale of the faithful. On this see Schoedel in Athenagoras, p. xi.

16 We note Leslie Barnard's favourable comments on the persuasiveness of these arguments in Athenagoras: A Study in Second Century Apologetic, Paris, 1972, p. 51, and in "Notes on Athenagoras," Latomus, 31 (1972), pp. 413-432, but cf. André-Jean Festugière's evaluation of Athenagoras as representing a 'mediocre' culture with learning set forth in topoi and doxai (contrasting him, along with most representative writers of this time, with the rare original souls such as Plotinus and Origen), in "Sur une nouvelle traduction d' Athénagore," REG, 1943, pp. 368-369. On the other hand Abraham J. Malherbe. "The Structure of Athenagoras, 'Supplicatio pro Christianis," vc, 23 (1969), pp. 1-20, points out that the limitations of his apologetic purpose - a purpose always to the fore - should "caution against our receiving the Supplicatio as a full exposition of his philosophy" (p. 20), and in "Athenagoras on Christian Ethics," JEH , 20 (1969) pp. 1-5, he concludes that despite the focus on revealed knowledge, Athenagoras makes fruitful use of philosophical topoi. 


\section{Roman Rule and God's Rule: Two Models of Kingship}

\section{Justin}

The Christian attitude to their rulers is one of compliance (1Ap.17.3-4) and yet because there have been cases of persecution there is a need to address the issue of unfair treatment. The fate of previous rulers is one way to do this without criticism being levelled at the current holder. Thus (in 1Ap.18.1) Justin alludes to the death of earlier, possibly ill-fated, emperors, and similarly the prefect Urbicus is rebuked as not doing honour to the ruler by his ill-advised judgement ( $2 A p$. 2.16). At intervals Justin returns to the language appropriate to the legal presentation of a case, for example appealing for a fair hearing and implying that the emperors, for their own good, would do well to listen to his account of Christian belief and respond to his counter-accusations.

Indeed Justin is not averse to making comparisons between the loyalty to God of Christians and that of Roman soldiers to their leader (1Ap. 39.5). The request to the state to assess the case against 'false' Christians with all due process (1Ap.1.56.3), presupposes common ground. Despite the citing of the quotation from Psalm 109 in $1 A p .45 .5$ relating to a sceptre being sent forth from Jerusalem, which might suggest a rival to the emperor, a basis for discussion is assumed in the midst of assertions on spiritual leadership, and the political legitimacy of the status quo is taken for granted, with the concept of separate spheres. Yet in the long run Christ will reign, Justin has no doubt (1Ap. 41.1), and will exercise true kingship. So too the condemned are described as cheerfully welcoming delivery from the earthly ruler to the father and king of heaven (2Ap. 2.19).

Justin's explanation for the existence of the current hostility to Christianity is the presence of demonic forces at work in the world undermining and mimicking the real deity ( $1 A p .5,14.1$ and 54$),{ }^{17}$ a persistent underlying theme. Justin at times does attack magistrates and judges, described as unwittingly serving

17 On this see Elaine Pagels, “Christian Apologists and 'The Fall of the Angels': An Attack on Roman Imperial Power?” HTR, 78 (1985), pp. 301-325, esp. pp. 304-306. Pagels takes the view that Justin and other apologists were not prepared to accommodate themselves to the ruling power on account of the demonic forces upholding it. This view seems to discount the more diplomatic passages to be found here. As David Rankin notes in his From Clement to Origen: The Social and Historical Context of the Church Fathers, London and New York, 2006, the emperor is not actively condemned and persecution and other evil acts are regarded, tactfully, as deriving from evil spirits, and contrary to the emperor's actual wishes (pp. 102-103). Whether the emperor was ever made aware of Justin's work, the dire threats of punishment were balanced by moments of sweet talking, which might also have an effect on attentive Christian readers. 
the purposes of the demons $(2 A p .11 .1),{ }^{18}$ and devotes a considerable portion of his apology to elaborating on their impact on the world, as a force instigating evil and mistrust of the Christian message, although their success relies on the blameworthy susceptibility of men and women. With the quotation from Luke's Gospel regarding paying tribute to Caesar, expanded by Justin into mandating worshipping God only but in other things gladly serving the emperor, and with a prayer that he may exercise sound judgement (1Ap.17.3), we see Justin performing a careful balancing act.

Justin also accepts that rulers exercise authority in criminal matters with divine sanction (1Ap. 7.4 and cf. 1 Pe. $\left.4 \cdot 15^{-16}\right)$. At one level this is an approach that might make disobedience problematic, but taken in conjunction with the focus on the spiritual kingship, the source of all earthly authority, there is room for a separation between due deference and explicit and outward obedience in all circumstances.

\section{Athenagoras}

For Athenagoras too there are two kinds of kingship. Human kingship is accepted but has value only when seen as providing a deputy for God's rule, whose kingdom rulers should strive to imitate (Leg.18.2). He asserts that we Christians "are most pious and righteous in relation to the divine and your kingdom" (Leg.1.3). The rulers who are the recipients of this speech, and addressed as $\mu \varepsilon^{\prime} \gamma(\sigma \tau 0 l$ $\alpha \dot{\tau} \tau o x \rho \alpha \tau o ́ \rho \omega \nu$, are assumed to fulfil their designated role, and their being termed philosophers gives, it seems, added security. It makes sense therefore for Athenagoras to suggest that, in response to his prompting.


themselves Leg.18.2).

Rulers may thus be described as good and wise (e.g. in Leg.31.3 and 37.1), and we note also Leg. 6.2 and 7.3, where we find Athenagoras using the common tactic employed by many advisors to kings of endeavouring by flattery and encouragement to bring about the ethical behaviour they are encouraging. While this may seem wildly optimistic in the case of Seneca's advice to Nero in the $D e$ Clementia, observing the convention in the Legatio indicates an understanding of how things are done, even if the work in question will never be viewed or heard by members of the imperial bureaucracy, let alone the emperor himself. Rulers may be chidden in absentia for not carrying out their God-given task.

We may ask whether, as has been suggested, Athenagoras also sees imperial rule as essentially demon-driven, because of its connection to a system of polytheism and veneration of the emperor which could only be explained by the

18 We note the reference in $2 A p \cdot 10.4$ to being dragged before the dikastēria. 
perverse workings of spirits rebelling against God and maliciously imitating features of Christian worship and doctrine. Is he perhaps able to separate the state as an institution for maintenance of human society from its currently deplorable features within the imperial system, including the persecution of loyal Christians? Certainly in chapters 24-25 Athengoras explains the evil situation resulting in the persecution of the good as the work of demons, and clearly differentiates the prophetic and cosmic elements operating in the world. In this he closely resembles Justin. ${ }^{19}$

The reference to the demonic forces at play has been taken by some scholars, as we have noted, to suggest that this is, by implication, a wholesale attack on the Roman civic authorities who are exercising a fraudulent imitation of divine power. If so it is clear that the emperor or his appointed officials would be bound to do all they could to suppress such a challenge to their exercise of authority. Yet Athenagoras does not go as far as to condemn the prevailing political system. Admittedly, rulers are implicated in this transaction between earthly and demonic forces, since kings have often been elevated to divine status (Leg. 28.6), and yet kings do have greater wisdom than others (Leg. 31.3), as Athenagoras tells his readers or auditors, suggesting that they should know better than the masses where the truth is to be found.

In fact his criticism is generally muted, and the conclusion of his address is full of terms of praise. ${ }^{20}$ Those addressed are "worthy of their royal office" (Leg.37.1), which is assumed to be a noble occupation. The request to them is simply for Christians to be allowed to live a peaceable life in the words of the Letter to Timothy (Leg.37.3).

\section{$3 \quad$ Pagan and Christian Values - Overlap or Essential Incompatibity?}

\footnotetext{
Justin

Part of Justin's argument revolves around claiming qualities generally regarded as positive for the Christian cause, at the same time as he challenges some assumptions. Christians have been accused of atheism, sedition and immorality. His rebuttal will attack these charges head-on. Thus he presents the novelty, for non-Jews at least, of Christian belief in one God as related to truth, whereas custom $(\tau \dot{\alpha} \hat{\varepsilon} \theta \eta)$, here depicted as the opposite of what is true, is to be regarded with suspicion (1Ap.12.6). Those who seek to maintain ancient tradition ( $\tau \dot{\alpha}$

19 See again Pagels, "Christian Apologists and 'The Fall of the Angels," p. 310.

20 Robert M. Grant, Greek Apologists of the Second Century, Philadelphia, 1988 describes this as adulation of the emperors (p. 101), which seems fair comment..
} 
$\left.\pi \alpha \lambda \alpha \dot{\alpha} \varepsilon^{\prime \prime} \theta \eta\right)$ and accuse the confessors of Christ of challenging this are in the wrong (1Ap.49.6). The new may be good - a counter-cultural claim in itself. ${ }^{21}$

When not arguing that custom may be regarded as suspect, Justin may adopt the contrary position, claiming that Christian thought is not in fact new, being based on Hebrew prophecies, preceding Greek philosophy (1Ap.23.1). ${ }^{22}$ So too pagan practices are a perverted imitation of Christian acts of worship and, like tales of the gods and their generation and deeds, are demon-inspired attempts to prevent people from perceiving the truth (1Ap.24-27).

While the masses, in contrast to the enlightened ruler, may be dismissed as easily misled (2Ap.8.3), and prone to listen to malevolent and long-stand-

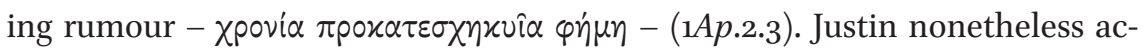
knowledges that simple folk are among those responding to the message of the gospel (1Ap.39.3 and cf. $2 A p .10 .8$ where artisans are described as among the congregation.) In case anyone, however, might consider that this entitles the Christian way to be of no account because of its lowly adherents, Justin adds "good pagans" such as philosophers to the unlearned as potentially receptive to the message he conveys, and thus an illustration of the power of God (2 Ap.10.46).$^{23} \mathrm{He}$ is also content to refer to Xenophon's account of Hercules' encounter with the two women illustrative of the paths of virtue and vice (2Ap. 11.2-8), to help him make his case for the Christian way of life.

We may note that Wilken has argued that early Christian groups showed many similarities to schools of philosophy, and this may be an obvious conclusion when Justin the philosopher is under discussion. ${ }^{24}$ Certainly he was happy to retain the title of philosopher as a Christian and gave instruction to followers, although this would not ensure his safety, and the rivalry of the Cynic Crescens might well have been a factor in his arrest and condemnation. Phi-

21 See Frances M. Young, Biblical Exegesis and the Formation of Christian Culture, Cambridge, 1997, p. 52: "Nothing could be both new and true: such was the assumption, such the challenge Christian apologists had to meet."

See Arthur Droge on Moses and Plato and the alleged influence of the former on the latter - A. Droge, "Justin Martyr and the Restoration of Philosophy," CH, 56 (1987), pp 303-319. It is possible that such comparisons were not always helpful, since philosophers were not infrequently seen as potential enemies of the Roman state. On this see Ramsay MacMullen, Enemies of the Roman Order, Cambridge, Mass., 1966, Ch.2. Musonius Rufus, Dio Chrysostom, in some episodes Apollonius of Tyana, and of course Socrates, were not always well-regarded by the state apparatus. Addressing an emperor who could himself be termed a philosopher presumably lessened the negative associations that the term might contain.

24 See Robert L. Wilken, "Towards a Social Interpretation of Early Christian Apologetics," $\mathrm{CH}$, 39 (1970), pp. 437-458. 
losophers themselves were often accused of inconsistency of life and doctrine, as Lucian of Samosata was only too happy to point out. On the other side, as we know, philosophers were themselves susceptible to charges of disloyalty, and the role of philosopher did not necessarily provide a cloak of security.

Christ is presented as a teacher from early on in the First Apology, and as pre-eminent in wisdom ( $1 A$ p. 22.1), and the argument is couched as an attempt to dissipate ignorance by the application of truth (1Ap.12 and see also $1 A p .23 .2)$. "Our teacher foretold", Justin says--referring to the one who is both Son and Apostle of God (1Ap.12.9). In accordance with this, the teachings of Christ are presented as in many cases in harmony with those of respected philosophers such as Socrates and Heraclitus (1Ap. 20-21), or having resonance with pagan myths but with the advantage of being true (1Ap.23.1). In all of this, Justin presents himself as both immersed in the culture he alludes to, but also at a distance. (Thus he refers to "your writers" when he brings forward witnesses from Greek literature to support his case, $\left.{ }_{1} A p .36 .2\right)$. Christians also teach (2Ap.2.9), and we note how this is seen as a battle against ignorance. Teaching, reason and truth are terms that are frequently linked to the message Justin is putting forward, and these all have positive resonances among his potential auditors.

Logos, as reason or as the Word present in Jesus Christ, is described as most kingly and just, a Stoic commonplace but nevertheless a significant challenge in a work directed, in theory at least, to the emperor (1Ap.12.7). Helleman, discussing the approach of Justin, relating specifically to the word logos, finds the employment of the term as consistent with his appeal, at least avowedly, to emperor and senate on the basis of "what is best in their culture " using terminology which is "already familiar on a broad spectrum." ${ }^{25}$ The picture presented is of teaching from and about Jesus Christ, the logos, to overturn or in some instances supplement the work of the logos present in some philosophers at least, before Christ.

When Justin, as often, refers to Jesus as teacher and to his instructions as teachings this is often in the context of comparisons made to the disadvantage of the pagans between the logos-based Christian teaching and the errant, demon-inspired beliefs and behaviour to which his auditors were susceptible. The coherence of word and deed was a key element emphasized in his refutation of the accusations made against Christians. This focus on actions meant that truth is often linked closely with goodness in Justin's account of the Christian proclamation, as in $1 A p$. 2.1 with reference to the instructions that sound reason ( $\left.\delta \sigma \dot{\omega} \varphi \rho \omega \nu \lambda \hat{o}_{\gamma} \circ\right)$ provides. His disavowal of arguments favoured by lo-

25 Wendy Elgersma Helleman, "Justin Martyr and the 'Logos': An Apologetical Strategy," Philosophia Reformata, 67.2 (2002), p. 145 (italics in the original). 
quacious sophists and his recommendation of the concise maxims of Christian teaching are consistent with this position (1Ap.14.4-5.)

Much of Justin's apology is a defence based on the claim that the life, death and resurrection of Jesus are the fulfilment of prophecies in the Hebrew Scriptures, regarded as authoritative because God-inspired. This comprises roughly a third of the First Apology. He does not directly engage with the issue of such authority as a credible source, compared to evidence from reasoning or observation, but claims that such a source must be more reliable than any fallible human agency. Those who become Christian are exercising freewill, a capacity of human beings asserted by Justin in opposition to a Stoic position which, he alleges, would deny this as a possibility $\left({ }_{1} A p \cdot 43^{-4}\right)$. Christians thus become children of liberty and knowledge ( $1 A p$. 61.10), a transformation seen as brought about by the enlightenment of baptism.

\section{Athenagoras}

Athenagoras also has to argue on two fronts. Yes, artisans are joining the movement (Leg.11.4) but this is no disgrace. Yet when what is xovvós is associated

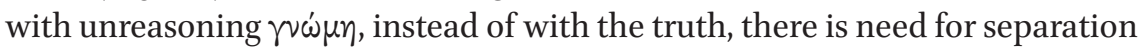
of the foolish masses from those enlightened if simple individuals who have embraced the Christian way of life (Leg.11.1). Here the simple folk and the old women normally despised by the educated are acknowledged as forming an important part of the Christian community and perhaps constituting its best advertisement by the powerful impact of their lives. Negative expressions relating to "the many" do, however, occur (such as in Leg.31.2, on "the opinion of the many", and Leg. 15.1 - the many are not able to judge), and Athenagoras is careful to separate truth and opinion (Leg.25.2) .

Athenagoras like Justin lauds reason and considers that Christian argument will not be found wanting, and Leg. 25.3 and 19.2 are good examples of this. It is in fact on the basis of reason that Athenagoras puts forward the claim of prophecy as a reliable guide. ${ }^{26}$ Human opinion unaided by divine inspiration is depicted as fallible, and thus the reasonableness of listening to the prophets is asserted as opposed to reliance on mere opinion, when Athenagoras explains the role of the Son and the Spirit (Leg.6.2; 7.3; 10). Human laws are contrasted with the teaching (logos) of the Christians (Leg. 32.4), and yet rulers are assumed to be well-versed in everything (Leg.24.1) and hence fair debating partners. The rationality of creation is argued for (Leg.25.3), but for Athenagoras, as for Justin, argument from prophecy is the most persuasive weapon in

26 On the place of the prophets see Jeffrey Bingham, “We have the Prophets': Inspiration and the Prophets in Athenagoras of Athens," ZAC, 20 (2016), pp. 211-242. 
the Christian's armoury, although the former does not intersperse his work with biblical references as liberally as Justin does.

Like Justin, however, Athenagoras sees rumour - $\varphi \eta \dot{\mu \eta}$ - as a key element in the difficulties faced by his co-religionists. This is associated with the words koinos and akritos (Leg.2.1) to imply the unreliability of the judgement of the many. In response to the charges commonly circulated, Athenagoras is at pains to emphasize that Christians are dutiful citizens (Leg.3.2) and the rulers themselves are called as witnesses to this. Christians display the virtues of non-retaliation (Leg.1.3) and adherence to truth (Leg.11.1). This differentiation is resumed in Leg. 33-36 with the rebuttal of accusations against the Christians on the grounds of their alleged immorality. Like Justin Martyr, as well as such pagan authors as Lucian of Samosata and other writers of the era, he derides those who see the task of philosophy as analyzing terminology and expounding syllogisms, and decries the focus on speech where the deeds do not match up to the language (Leg.11.3). This of course does not prevent him from using all the linguistic resources at his command to argue his case!

\section{The Tone of These Works}

\section{Justin}

As Justin describes the place of Christians (1Ap.12.1-4) they may be regarded as allies of the emperor in encouraging lawful and decent behaviour, and not "mad, bad or dangerous to know!"27Nonetheless there is in one sense a daring appraisal of imperial rule being made when Justin asserts that rulers who do not pay heed to what is right are no better than brigands in a desert (1Ap.12.6). ${ }^{28}$ That the work Justin is engaged on is not a merely theoretical debate emerges when he refers to the death penalty imposed on Christians and speaks directly to the 'you' held responsible for this, presumably the emperor himself and his administration (1Ap.2.4). While Justin's best move might seem to be to ease up on the more polemical features of the Gospel message, he does not hold back

27 That such reassurances might be necessary is clear not merely from the more extreme accusations circulating about Christians, but also because of the general disapproval they were likely to encounter. As Munier notes (Apologie, p. 49), "D’aucuns leur reprochent leur inutilité sociale et leur indolence civique; certains même insinuent que, se tenant volontairement en marge de la cité, ils sont en fait rebelles à la chose romaine et conspirent à sa perte".

28 We may compare this comment with the assertion by the pirate to Alexander the Great as recounted in Augustine's Civitas Dei, 4.4 that an empire without justice is licensed brigandage. 
from exhorting the imperial power to heed his words so as to avoid divine punishment (2Ap.11-12). He notes that death is decreed against those who teach about or in any way confess the name of Christ ( $1 A p .45)$ and does not hesitate to suggest that those who oppress Christians will themselves suffer for eternity. Yet he concludes the Second Apology by asking "you (the emperors) to judge with justice as befits your piety and philosophy" (2Ap.15.5).

In considering Justin and his writings it is obvious that we do not have a sense that he was fighting an ongoing battle with the world, the state or the surrounding culture, as he adopts the role of spokesperson to his imperial dedicatees in the apologetic works. "Even in the case of the Apologies, the imperial and senatorial audience is not to be taken wholly seriously," concludes Rajak, so that this may be a shadow-boxing exercise in a sense, but nonetheless with a serious purpose for all that. ${ }^{29}$ So too we note that in the Dialogue with Trypho he engages with a sympathetic, not to say tolerant, dialogue partner (all the better for being given few lines to speak). Compared to the fiery exchanges in the doctrinal writings of the fourth and subsequent centuries and the encounters which set Christians at odds with the state in the amphitheatre in the periods of sustained persecution (including that involving Justin himself) the writings under consideration may appear fairly tame as works of controversy, designed to allay suspicions rather than rouse imperial hackles. They express the resolution to confront this issue with reason and argument when it might have been tempting to retreat into isolation or adopt the hostility of the Book of Revelation. ${ }^{30}$

\section{Athenagoras}

Athenagoras' tone, despite being in general mild and conciliatory, is not always irenic, and his terminology is frequently redolent of the court of law, with mention of defending a case ( Leg.17) and the adoption of a polemical tone (Leg.18) For Athenagoras, it is important to emphasize that the law entitles the citizensubject to fair treatment, and thus Christians being persecuted for no good reason may reasonably appeal for their vindication to the law that appears to condemn them (Leg.1.3). Legal terms relating to the production of witnesses and to prosecution appear often (Leg.3.2) and are linked to the fate of innocent

29 Rajak, 'Talking at Trypho', p. 75.

$30 \quad$ Eric F. Osborn, Justin Martyr, Tubingen, 1973, asserts that " all the dialectical subtlety and rhetorical skill of later classical antiquity" were turned against the Christian claims (p. 5). This had yet to be unleashed in Justin's era, but in Osborn's chapter on the apologists in Esler (ed.) The Early Christian World, he sets out the case for Justin as the one laying out the framework for future Christian defences against such attacks. 
victims of wrongly administered law, such as Socrates, and we may note here Leg.7.1 where the freedom of others to have their say is contrasted with the fate of Christians who try to set out their case. The inner law is what guides the conduct of Christians, so they have no need to attend to human laws which some citizens may in any case escape ( $\mathrm{Leg} . \mathrm{3}^{2.4}$ ). Nonetheless the contrast between the rulers and those pursuing the Christians through the courts (Leg. 1. 3-4) highlights the separation being sought in this work between the blameworthy persecutors and the misled rulers.

\section{$5 \quad$ Conclusion}

The imperial authorities were unlikely, on balance, to have read or even heard of these texts. Their response, had they done so, would hardly have been positive, but it is possible that a reassurance that Christians were loyal subjects in all but one area might have lessened their security concerns about the group, while leaving them a scapegoat for hard times. In the same way governments today, responding to perceived terror threats, might find assurances of loyalty by mainstream Moslem citizens a relief, but still on occasions employ references to outliers in the midst of society as a handy diversionary tactic.

One interpretation of the conflict recounted here may be to see it as a matter of presenting an alternative interpretation of the world, challenging the status quo on different levels. There is perhaps most obviously the challenge to the view of the cosmos and the human story - the putting forward of a narrative featuring as hero an individual from an ethnos generally regarded as recalcitrant in respect of imperial values, whose social standing gave him no acceptable claim to an exalted role in society. Legatio 11.3 asks for freedom of speech before the emperor, to expound this vision.

The direct imagined or intended addressees being in both cases an emperor or heirs of the emperor were at this stage highly unlikely to be receptive to the messages contained in these works. The situation had none of the potential for mutual advantage found by Constantine and the Christians of his acquaintance well over a century later. The world view of the second-century Christian does not present the emperor as a superior cosmic ruler whose kingdom may still allow for power-sharing in the form of devolution, but rather envisages a differently-ordered, spiritual world. If any enemy is foregrounded, it is the cosmic demonic forces alluded to so frequently by both writers, but with special force by Justin. They are held responsible for the rejection of Christ, although their human agents are nonetheless complicit and guilty. The message of love 
and compassion is there, but sometimes obscured by the sense of impending judgement. ${ }^{31}$

However, it is perhaps not surprising that despite the reservations of some scholars, Justin's work in particular has been seen as displaying an openness to the world and especially to philosophical thought, with its references to the Logos disseminated throughout the world, although manifested fully only in the person and message of Jesus Christ. This has been taken as a warrant for, or example of, universalism in contact between Christians and non-Christians. Whether Justin himself would have extended tolerance to non-believers within a Christian state it is impossible to say, since such a scenario would have been unthinkable in his day. ${ }^{32}$

Athenagoras, by adopting the tone of a rational individual addressing those in authority who would be susceptible to the truth, if properly presented, also emerges as a person bent on conflict resolution, although in the process his writing is more precisely directed at rebutting false charges and expounding a reasonable view of the cosmos where demonic forces are ultimately disarmed.

$31 \quad$ This aspect is not perhaps given due weight in the very positive assessment of Justin's message as one of consolation and good news in Osborn's chapter on the apologists, noted above, in Esler (ed.), The Early Christian World.

32 Nonetheless, the point made by Chadwick in relation to Justin's significance, that his work indicated the engagement from his time onwards of the church with the Gentile world and the empire, and vice-versa, is a valid one. See his "Justin Martyr's Defence of Christianity," BJRL 47 (1965), p. 287. 